for this purpose. The results showed that all pass and honours students obtained at least 40 per cent in classes 1, 2 and 3, whereas none of the failed studonts scored more than 40 per cent in these classes. Thus there was no difference in the result-so far as pass and fail were concerned-using this assessment based on the classification as compared with the overall percentage method. There was, however, a sonsiderable difference in the number of honours grades awarded, for different taxonomic gradings, one of which is as follows:

$\begin{array}{lccc} & \text { Honours } & \text { Pass } & \text { Fail } \\ \text { Overall percentage grading } & 25 & 93 & 32 \\ \text { Taxonomic grading } & 40 & 78 & 32\end{array}$

The conclusion appears to be that considerable care is needed, particularly at the upper end of the scale, if examining is to provide an accurate assessment of what is sought from students.

\title{
SALARIES OF UNIVERSITY TEACHING STAFFS IN BRITAIN
}

$\mathrm{N}$ a written answer in the House of Commons on 1 March 14, the Chief Secretary to the Treasury, Mr. H. Brooke, stated that the Government had considered the recommendations of the University Grants Committee for recurrent grants for the fiveyear period 1962-67. It had also considered substantial increases in the salaries of university teaching staffs with the determination to effect the most rapid development of higher education that is consistent with other claims on the nation's prospective economic resources in the next five years and with the Government's policy for incomes. These considerations had made it necessary to depart from the Committee's recommendations and he had informed the Committee that, subject to annual approval of the Estimates by Parliament in the normal way, it should plan on the basis of the following recurrent grants from August 1 next: 1962-63 £56 million; 1963-64, £60.5 million; $1964-65$, 665.5 million; 1965-66, £70.5 million; $1966-67, £ 76.5$ million. The grant for the present university year is $\$ 49.5$ million. These figures exclude provision for rates, which will be financed by special grants outside the quinquennial settlement, and the cost for the universities of the Grovernment's recent request for an increase in the intake of medical students had yet to be finally settled and would also be additional to these figures.

Mr. Brooke reaffirmed the undertakings given last year on the rapidly increasing provision for nonrecurrent grants and added that the awards to university students from public funds was also continually growing. In sum, the aggregate cost of the universities to public funds had increased from $£ 50$ million to $£ 104$ million during the past five years and might increase by at least $£ 50$ million in the next five years.
The universities' estimates, including those of the seven new universities authorized during the present quinquennium, indicated that, given adequate financial support, they would be prepared to work to an expansion of the total student population from about 111,000 in $1961-62$ to about 150,000 in 1966-67. Mr. Brooke had asked the University Grants Committee to inform the universities that it was the Government's wish that the additional funds should be applied so far as possible to achieving the figure of 150,000 . The Government's aim was to continue the expansion to about 170,000 places by $1973-74$. These recurrent grant figures are based on rates of academic salaries which came into effect in January 1960. The Government had taken carefully into account the strong arguments advanced by the University Grants Committee for a substantial increase in these salaries, along with the need to expand the teaching staff in relation to the increase in student numbers, but did not feel able to authorize an increase of more than 3 per cent in the bill for academic salaries. Scales based on an aggregate increase of this order would be authorized from April 1, 1962, and would cost about $£ 1$ million extra in the first full year. The scales would be reviewed afresh next year. Provision for university expansion was only part of the resources that the Government was devoting, on an increasing scale, to higher education; and all these programmes might need to be re-examined in two or three years' time in the light of the report of the Robbins' Committee on Higher Education. The Government's proposals for the first year of the new quinquennium and for the increase in salaries would necessitate a supplementary estimate of some $\mathfrak{£ 4 . 5}$ million for 1962-63.

\section{RHEOLOGY OF CLAY SOILS}

\begin{abstract}
$\mathrm{T}$ the meeting of the Cambridge Rheology Club held on February 5, Mr. W. J. Thompson Department of Engineering, University of Cambridge) spoke on the "Rheology of Clay Soils". He pointed out that it is current practice in soil mech. anics to use the triaxial apparatus to study the shear charactoristics of a soil. In this apparatus a cylindrical sample of soil can be subjected to any desired combination of axial and hydrostatic stresses, the sample being either allowed to drain during the deformation process (drained test) or be maintained at a constant volume (undrained test). The allowable shear strength value used in soil mechanics com.
\end{abstract}

putations is taken as some proportion of the maximum shear stress $\tau_{m}$ obtained in a constant axial strainrate triaxial test, although corresponding tests with constant axial stress have indicated that for stresses $>0.8 \tau_{m}$ a state of structural disintegration is obtained. Consideration should therefore be given only to the region of the stress-range $\left(<0.8 \tau_{m}\right)$ within which the soil would behave in the field. Present shear theories are generally based on the results of constant strain-rate tests and neglect time considerations.

The existence of a yield-point in the shear deformation of clays, as investigated by Bingham and scott 